
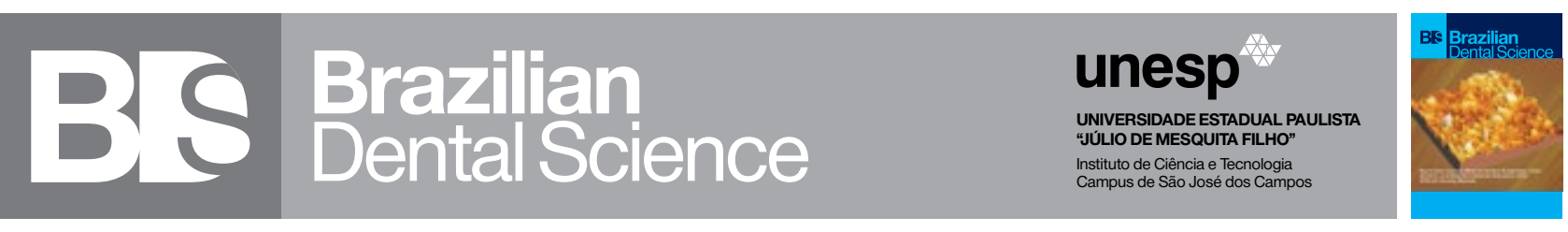

\title{
Estimation of the autoclave and different surface treatments on microleakage between soft liner and heat-cured acrylic
}

Estimativa da autoclavagem e diferentes tratamentos de superfície na microinfiltração entre o soft liner e o acrlico termopolimerizável

Hawraa Khalid AZIZ ${ }^{1}$, Shurooq Falih HASAN ${ }^{1}$

1 - Middle Technical University (MTU), Department of Prosthetic Dental Technology, College of Health and Medical Technologies, Baghdad, Iraq.

\section{ABSTRACT}

Objective: The present study was oriented to estimate the effect of different surface treatments on the microleakage between the soft liner and acrylic with and without the use of autoclave as disinfection method. Material and Methods: Sixty samples were split into two groups: the autoclaved groups and non-autoclaved groups. Each one subdivided into three groups: first one without any treatments as a control group; in the second group surface of the samples were treated with $\mathrm{CO}_{2}$ laser $(10.6 \mathrm{~nm}$ wavelength for 15 seconds), and in the third group the surface was treated with sandblasting $(250 \mu \mathrm{m}$ $\mathrm{Al}_{2} \mathrm{O}_{3}$ ). All the samples exposed to thermocycling, then the microleakage test was evaluated by gauging dye penetration depth between the soft liner and acrylic disc using a digital microscope. Data analyzed statistically by One-way ANOVA and Tukey's post-hoc tests. In addition, t-test was used for comparison between two groups (P-value $\leq$ 0.05). Results: The maximum mean values for the microleakage were observed in the untreated group (control) followed by the group treated by $\mathrm{CO}_{2}$ laser and the lowest mean value of microleakage was related to the third group for both non-autoclaved and autoclaved groups with significant differences among them. In addition, depending on the use of autoclave, there was non-significant in all studied groups. Conclusions: There was a decrease in the microleakage when the surface treated with $\mathrm{CO}_{2}$ laser and sandblast. The use of autoclave did not badly change the microleakage between the soft liner and denture base.

\section{KEYWORDS}

Microleakage; Denture Liners; Autoclave; $\mathrm{CO}_{2}$ laser; Sandblast.

\section{RESUMO}

Objetivo: O presente estudo teve como objetivo estimar o efeito de diferentes tratamentos de superfície na microinfiltração entre o soft liner e o acrílico usando ou não a autoclve como método de desinfecção. Material e Métodos: Sessenta amostras foram divididas em dois grupos: grupo com uso da autoclave e grupo sem uso da autoclave. Cada um subdivide em três grupos: o primeiro sem nenhum tratamento como grupo controle; no segundo grupo, a superfície das amostras foi tratada com laser de $\mathrm{CO}_{2}$ (comprimento de onda de $10,6 \mathrm{~nm}$ por 15 segundos) e, no terceiro grupo, a superfície foi tratada com jateamento $\left(250 \mu \mathrm{m} \mathrm{Al}_{2} \mathrm{O}_{3}\right)$. Todas as amostras foram expostas à termociclagem, em seguida o teste de microinfiltração foi realizado medindo-se a profundidade de penetração do corante entre o soft liner e o disco de acrílico em microscópio digital. Os dados foram analisados estatisticamente por One-way ANOVA e testes post-hoc de Tukey. Além disso, o teste $t$ foi usado para comparação entre dois grupos (P-valor $\leq 0,05)$. Resultados: Os valores médios máximos de microinfiltração foram observados no grupo não tratado (controle) seguido pelo grupo tratado com laser de $\mathrm{CO}_{2}$ e o valor médio mínimo de microinfiltração foi relacionado ao terceiro grupo para ambos os grupos não autoclavado e autoclavado com diferenças significativas entre eles. Além disso, dependendo do uso de autoclave, não houve significância em todos os grupos estudados. Conclusão: Houve diminuição da microinfiltração quando a superfície foi tratada com laser de $\mathrm{CO}_{2}$ e jateamento. $\mathrm{O}$ uso de autoclave não alterou a microinfiltração entre o soft liner e a base da prótese.

\section{PALAVRAS-CHAVE}

Microinfiltração; Reembasadores de dentadura; Autoclave; Laser $\mathrm{CO}_{2}$; Jateamento. 


\section{INTRODUCTION}

$\mathrm{T}$ he soft liners have been widely utilized for prosthetic denture as a cushion on the tissue surface for removable dentures and maxillofacial prosthesis $[1,2]$ due to viscoelastic properties[3]. They belong to the resilient materials indicated for relining the inner surfaces of denture base to withstand the stressbearing area [4]. Liners are used when there are unfavorable sharp bothering edges, failure of the denture fitness inveterately [5]. As well as, they are also used for prostheses fracture and cleft palate [6], tissue conditioning during implant healing [7]. Soft liners are noninvasive and relatively more economical when compared to make a new denture [8] for both two liner categories: short or long-products because they remain more than one year for long-type denture liner and up to one month for short-type liner product [9].The patient prefers resilient liners over hard ones because they improve comfort [10]. The main problem associated with soft liner is the lack of bonding to the resin materials $[11,12]$. The deboning of soft liners from the denture base can create a potential surface for bacterial growth, plaque accumulation, and calculus formation [13]. The failure of adhesion may be attributed to the microleakage between them [14]. The microleakage defined as a major factor that is clinically undetected able to elapse of microorganisms from the oral cavity into the prosthesis, the success of the material depends on the ability to prevent microleakage [15]. The major output of the good adhesion strength is preventing microleakage [16]. Various surface pretreatments have been done to enhance the bond strength and evaluate microleakage between the liner and denture base [17]. Some of these are roughening the bonding surface by airborne-particle abrasion, laser, or by the monomer $[11,18]$.

On the other hand, the main interest of denture use is disinfection and controlling the contamination particularly in the prosthodontics branch [19]. Therefore, the indication of the autoclave as a sterilization method because of its good destroying of bacteria, fungi, viruses, and any reason that result in contamination of liquids and equipment in use [20].But some studies were reported that the specimens were suffered from the internal stress formation and shrinkage after heat postpolymerization, so to overcome this problem the specimens were left in the autoclaves for cooling to reduce shrinkage and internal stress formation $[21,22]$.

So, the aims of this in-vitro study were oriented to assess the effect of airborne particle abrasion with aluminum oxide and laser treatment on microleakage between soft liner and denture base. The null hypothesis consisted of two parts: the first part was the surface treatment with aluminum oxide, and laser treatment should not affect the microleakage between the liner and resin. The second part was microleakage between soft liner and denture base remain unchanged statistically after sterilization by autoclave.

\section{MATERIALS AND METHODS}

In this study sixty polymethylmethacrylate denture base resin (Heat-cured denture base resin, vertex, Netherlands) were supplied in a disc shape $(30 \mathrm{~mm}$ in diameter and $2 \mathrm{~mm}$ in thickness) [23], these specimens were heat cured in a water bath according to the manufacturer's directions which were processed by a short curing cycle $\left(74^{\circ} \mathrm{C}\right.$ for 1.5 hours then boiling for 30 minutes), then they were extracted from the flask and all flashes were trimmed and the accurate measurements of each specimen and verified by a caliper device (Renfert, Germany) from different points. The 60 specimens divided into three major groups depending on the surface treatments that were applied to each group as follow (Table I):

First group: 20 specimens did not receive any surface treatment (control group). 
Second group: 20 specimens in this group were subjected to laser machine $\left(\mathrm{CO}_{2}\right.$ laser, CMA-1080 kll, Yue Ming Laser Technology Co., Ltd, China) at power 6-15 Watts, 85-212 $\mathrm{J} / \mathrm{cm} 2$ energy [24] at $12.5 \mathrm{~mm}$ distance from exposed area to laser beam [25]. An aluminum metal plate mesh was made (the measurement of this metal plate mesh was equal to the dimension of the acrylic specimen) $\mathrm{CO}_{2}$ laser emitting radiation with continuous plus with a wavelength of $10.6 \mathrm{~nm}$ for 15 seconds on the treated surface [26]. The operator wore the specified eyeglass to protect the eye against the hazards of the $\mathrm{CO} 2$ laser beam.

Third group: 20 specimens were roughened by sandblasting machine (No.900036327, China) by airborne particle abrasion with $250 \mu \mathrm{m} \mathrm{Al} \mathrm{O}_{3}$ on the treated surface of a disc shape acrylic denture base resin at a pressure of $0.62 \mathrm{Mpa}$ for 30 seconds [17] a special holder was custom made to fix the tip of the nozzle and the specimen during the sandblast procedure without affecting the constant distance between the treated surface of the specimens and the tip of the nozzle.

Table I - Specimens grouping according to surface treatment type

\begin{tabular}{|c|c|c|}
\hline \multicolumn{2}{|c|}{ Study groups } & Treatment type \\
\hline \multirow{3}{*}{$\begin{array}{l}\text { Non-autoclaved } \\
\text { groups }\end{array}$} & Control & Without any treatment \\
\hline & Laser & Surface treatment with $\mathrm{CO}_{2}$ laser for 15 seconds \\
\hline & Sandblast & $\begin{array}{l}\text { Surface treatment with } 250 \mu \mathrm{m} \mathrm{Al} \mathrm{O}_{3} \text { for } 30 \\
\text { seconds }\end{array}$ \\
\hline \multirow{3}{*}{$\begin{array}{l}\text { Autoclaved } \\
\text { groups }\end{array}$} & Control & Without any treatment \\
\hline & Laser & Surface treatment with $\mathrm{CO}_{2}$ laser for 15 seconds \\
\hline & Sandblast & $\begin{array}{c}\text { Surface treatment with } 250 \mu \mathrm{m} \mathrm{Al} \mathrm{O}_{3} \text { for } 30 \\
\text { seconds }\end{array}$ \\
\hline
\end{tabular}

The specimens of acrylic cleaned in an ultrasonic device then removed and left for complete dryness. After that, the $2 \mathrm{~mm}$ of heat-cured soft liner material $\left(V^{2} e^{2}{ }^{\mathrm{TM}}\right.$ Soft, Netherlands) was applied on the treated surface of the acrylic by the aid of the mold followed by curing the soft liner according to the manufacturer's instructions that was polymerized by water bath at $70{ }^{\circ} \mathrm{C}$ for an hour and a half, then the temperature was raised to $100{ }^{\circ} \mathrm{C}$ for 30 minutes. In the end, we obtained disc specimens that had $30 \mathrm{~mm}$ in diameter and $4 \mathrm{~mm}$ in thickness $(2 \mathrm{~mm}$ for acrylic resin and $2 \mathrm{~mm}$ for soft liner). That was adapted by placing the heat cured acrylic specimen in the mold taking $2 \mathrm{~mm}$ of mold thickness, and the other $2 \mathrm{~mm}$ thickness was filled with soft liner material that was applied with aid of the split mold that was placed between two plates to extrude excessive material after a complete setting the specimen was removed from the mold [27]. Then all samples put in thermocycling (Julabo Labortechnix, GMBH, Germany) for subjecting to $\left(5 \pm 1{ }^{\circ} \mathrm{C}-55 \pm 1{ }^{\circ} \mathrm{C}, 500\right.$ cycles) for 60 seconds in an isolated container [28]. Then the autoclaved groups were exposed to the sterilization by autoclave (HICLAVE HV-25 L, HIRAYAMA, Japan) monitored as fellow: 121 ${ }^{\circ} \mathrm{C}$ temperature, 15 pound/inch ${ }^{2}$ pressure, and 15 minutes as immersion time, the diameter and thickness of each specimen was rechecking by vernier to exclude any distorted specimen [19]. In addition, the non-autoclaved groups remained without autoclave disinfection. After thermocycling and sterilization, the specimens of each group soaked in dye pigment (methylene blue) that was placed in an incubator for one week [27]. After the storage period was completed, they washed them with water and put aside to dry. Then 4 lines were delineated on the specimens to divide the diameter into 4 equal pieces by using a separating disc in a slow speed handpiece (Marathon, Korea) with continuous water cooling to avoid overheating of the specimens, then the specimen split into 8 pieces in equal measurements (Figure1), so each specimen had 8 readings for microleakage value that was done by measuring the amount of penetration of methylene blue dye between the acrylic disc and soft liner. The measurement done by a digital microscope (Dino-Lite, Taiwan) at a magnification of (40X) [29], the microscope 
had a camera that has captured images for each specimen, and the penetration of the dye evaluated in millimeter. Eight readings were recorded for each specimen, and the average of them was maintained to get one microleakage value for each specimen.

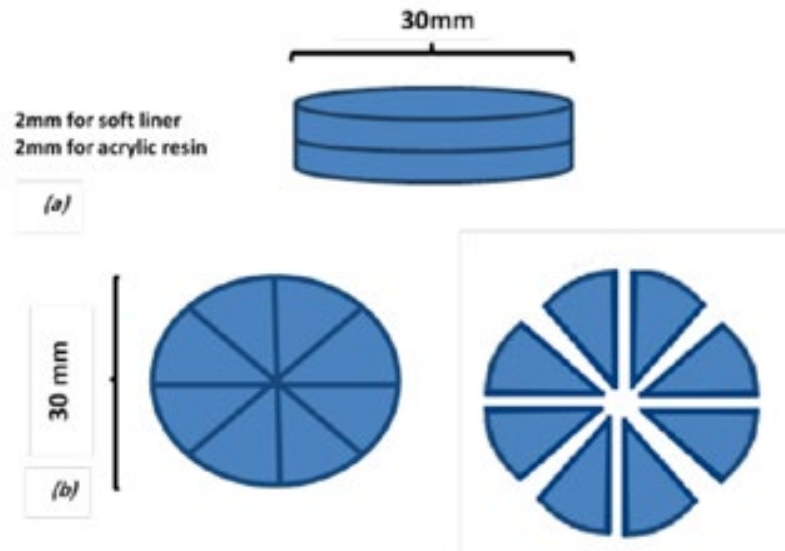

Figure 1 - The disc-shaped of the specimen for microleakage test (a); the specimen split into 8 pieces (b).

\section{Scanning electronmicroscopy (SEM):}

The changes in surface morphology of acrylic resin samples after surface treatments and before soft liner application were evaluated for all groups by using the a scanning electron microscope (SEM) (S 50, FEI Company, Netherlands). The SEM the images were taken at two magnifications: X 1000, X 2000 [30,31].

Statistically, the microleakage data of each group were analyzed by One-way analysis of variance (ANOVA) and Tukey HSD multiple comparison tests to determine the significant differences between the different surface treatments. The independent T-test was used for analyzing the difference between the autoclaved and non-autoclaved groups.

\section{RESULTS}

The descriptive statistics of microleakage with and without autoclave were presented in Table II, the maximum mean values for the microleakage were observed in the untreated group(control) followed by the group treated by $\mathrm{CO}_{2}$ laser and the lowest mean value of microleakage was related to the group treated by sandblasting with $250 \mu \mathrm{m} \mathrm{Al}_{2} \mathrm{O}_{3}$ for both groups without autoclave and the groups subjected to autoclave (Figure 2). One-way analysis of variance produced significant differences among all studied groups with and without autoclave (Table III). Further analysis to compare all groups using the Tukey-HSD test were showed significant differences among the tested groups (Table IV). The results of analyzing the autoclaved groups and non-autoclaved groups by using the independent t-test indicated a statistically non-significant difference between the microleakage values for all groups with and without autoclave (Table V). Figure 3 showed the microleakage which represented by dye penetration of the control groups was maximum penetration of the pigment for both groups autoclave and non- autoclaved groups (Figure 3, a and b). While, the dye breakthrough with less amount than control groups for the treatments with laser (Figure 3, c and d), and lest amount of dye was shown in sandblast with and without autoclave disinfection groups (Figure 3, e and f).

SEM analysis showed the surface topography of each surface treatment for autoclave and nonautoclave groups.There was a visual reduction in surface roughness in the control group and a uniform surface without any visual surface topography change (Figure 4, $a$ and b; Figure 5, a and b). For laser groups the SEM examination showed that the rough surface with many holes formations. Melted areas in the resin polymer and many cavities (Figure 4, c and d; Figure 5, c and d). While there was clearly rough surface on acrylic surface with scratches and appearance of micro porous and irregularities with sharp edge rims in sandblast groups (Figure 4, e and f; Figure 5, e and f). 


Aziz HK et al. $\quad \begin{array}{r}\text { Estimation of the autoclave and different surface treatments on } \\ \text { microleakage between soft liner and heat-cured acrylic }\end{array}$

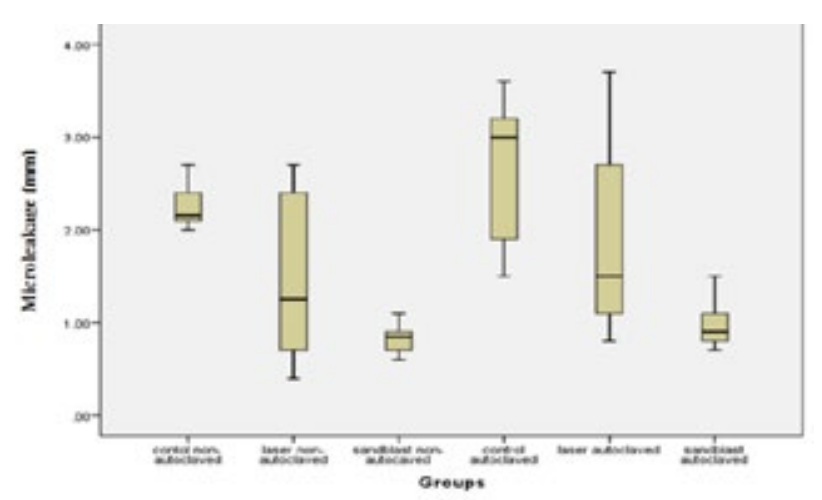

Figure 2 - Box plot of the microleakage for all tested groups.

Table II - Descriptive statistics of microleakage $(\mathrm{mm})$ for all groups

\begin{tabular}{|c|c|c|c|c|c|c|c|c|}
\hline \multirow{2}{*}{\multicolumn{2}{|c|}{ Study groups }} & \multirow[t]{2}{*}{$\mathbf{N}$} & \multirow[t]{2}{*}{ Mean } & \multirow{2}{*}{$\begin{array}{l}\text { Std. } \\
\text { Dev. }\end{array}$} & \multicolumn{2}{|c|}{$\begin{array}{l}\text { 95\% Confi- } \\
\text { dence Interval } \\
\text { for Mean }\end{array}$} & \multirow{2}{*}{$\begin{array}{l}\text { Min. } \\
\text { value }\end{array}$} & \multirow{2}{*}{$\begin{array}{l}\text { Max } \\
\text { value }\end{array}$} \\
\hline & & & & & $\begin{array}{l}\text { Lower } \\
\text { Bound }\end{array}$ & $\begin{array}{l}\text { Upper } \\
\text { Bound }\end{array}$ & & \\
\hline \multirow{3}{*}{$\begin{array}{l}\text { Non-au- } \\
\text { toclaved } \\
\text { groups }\end{array}$} & Control & 10 & 2.25 & 0.2369 & 2.081 & 2.419 & 2.0 & 2.7 \\
\hline & Laser & 10 & 1.53 & 0.9031 & 0.884 & 2.176 & 0.4 & 2.7 \\
\hline & Sandblast & 10 & 0.84 & 0.1713 & 0.717 & 0.963 & 0.6 & 1.1 \\
\hline \multirow{3}{*}{$\begin{array}{l}\text { Autoclaved } \\
\text { groups }\end{array}$} & Control & 10 & 1.54 & 0.7890 & 1.245 & 1.835 & 0.4 & 2.7 \\
\hline & Laser & 10 & 2.71 & 0.7202 & 2.194 & 3.225 & 1.50 & 3.60 \\
\hline & Sandblast & 10 & 1.84 & 0.9720 & 1.144 & 2.535 & 0.80 & 3.70 \\
\hline
\end{tabular}

Table III - One-way ANOVA for comparison the microleakage between groups according different surface treatments in autoclaved and non-autoclaved groups

\begin{tabular}{|c|c|c|c|c|c|c|}
\hline \multicolumn{2}{|c|}{ Study groups } & $\begin{array}{l}\text { Sum of } \\
\text { Squares }\end{array}$ & Df & $\begin{array}{l}\text { Mean } \\
\text { Square }\end{array}$ & F-value & P-value \\
\hline \multirow{3}{*}{$\begin{array}{l}\text { Non-autoclaved } \\
\text { groups }\end{array}$} & $\begin{array}{l}\text { Between } \\
\text { Groups }\end{array}$ & 9.942 & 2 & 4.971 & \multirow[t]{3}{*}{16.550} & \multirow[t]{3}{*}{$0.000^{\star}$} \\
\hline & $\begin{array}{l}\text { Within } \\
\text { Groups }\end{array}$ & 8.110 & 27 & 0.300 & & \\
\hline & Total & 18.052 & 29 & & & \\
\hline \multirow{3}{*}{$\begin{array}{l}\text { Autoclaved } \\
\text { groups }\end{array}$} & $\begin{array}{l}\text { Between } \\
\text { Groups }\end{array}$ & 15.138 & 2 & 7.569 & \multirow[t]{3}{*}{14.837} & \multirow[t]{3}{*}{$0.000^{*}$} \\
\hline & $\begin{array}{l}\text { Within } \\
\text { Groups }\end{array}$ & 13.774 & 27 & 0.510 & & \\
\hline & Total & 28.912 & 29 & & & \\
\hline
\end{tabular}

*; significant at P-value $\leq 0.05$
Table IV - Tukey HSD-test for Multiple comparison between different treatment groups control, laser, and sandblast) in autoclaved and non-autoclaved groups

\begin{tabular}{|c|c|c|c|c|c|}
\hline \multicolumn{3}{|c|}{ Study groups } & \multirow{2}{*}{$\begin{array}{c}\text { Mean } \\
\text { Square } \\
0.7200\end{array}$} & \multirow{2}{*}{$\begin{array}{c}\text { F-value } \\
0.2451\end{array}$} & \multirow{2}{*}{$\begin{array}{c}\text { P-value } \\
0.018^{\star}\end{array}$} \\
\hline \multirow{3}{*}{$\begin{array}{l}\text { Non-autoclaved } \\
\text { groups }\end{array}$} & Control & Laser & & & \\
\hline & Control & Sandblast & 1.4100 & 0.2451 & $0.000^{\star}$ \\
\hline & Laser & Sandblast & 0.7200 & 0.2451 & $0.018^{*}$ \\
\hline \multirow{3}{*}{ Autoclaved groups } & Control & Laser & 0.6900 & 0.2451 & $0.024^{*}$ \\
\hline & Control & Sandblast & 1.4100 & 0.2451 & $0.000^{*}$ \\
\hline & Laser & Sandblast & 0.6900 & 0.2451 & $0.024^{*}$ \\
\hline
\end{tabular}

*; significant at $\mathrm{P}$-value $\leq 0.05$

Table V - Independent T-test for comparison between autoclaved and non-autoclaved groups in control, laser, and sandblast groups

\begin{tabular}{|cccc}
\multicolumn{2}{c}{ Study groups } & F-value & P-value \\
\hline $\begin{array}{c}\text { Non-autoclaved Control } \\
\text { group }\end{array}$ & $\begin{array}{c}\text { Autoclaved Control } \\
\text { group }\end{array}$ & 1.919 & $0.071 \mathrm{~ns}$ \\
$\begin{array}{c}\text { Non-autoclaved Laser } \\
\text { Group }\end{array}$ & Autoclaved Laser group & 0.739 & $0.470 \mathrm{~ns}$ \\
$\begin{array}{c}\text { Non-autoclaved Sand- } \\
\text { blast group }\end{array}$ & $\begin{array}{c}\text { Autoclaved Sand- } \\
\text { blast group }\end{array}$ & 1.326 & $0.201 \mathrm{~ns}$ \\
\hline
\end{tabular}

ns; non-significat at P-value $>0.05$

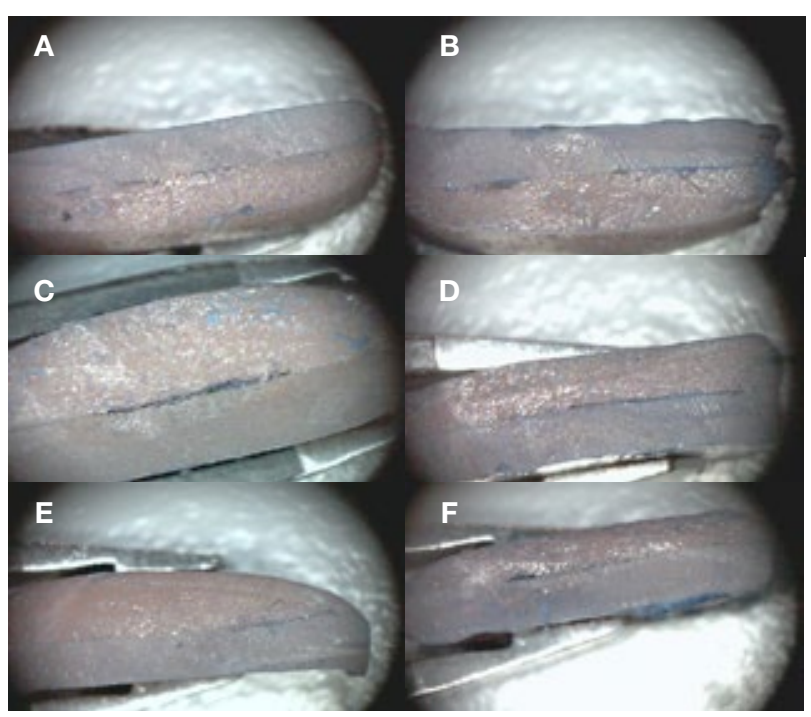

Figure 3 - (a-f).Microleakage for control groups nonautoclave(a) autoclave (b); Laser groups nonautoclave (c)autoclave (d);sandblast groups nonautoclave (e) autoclave (f). 


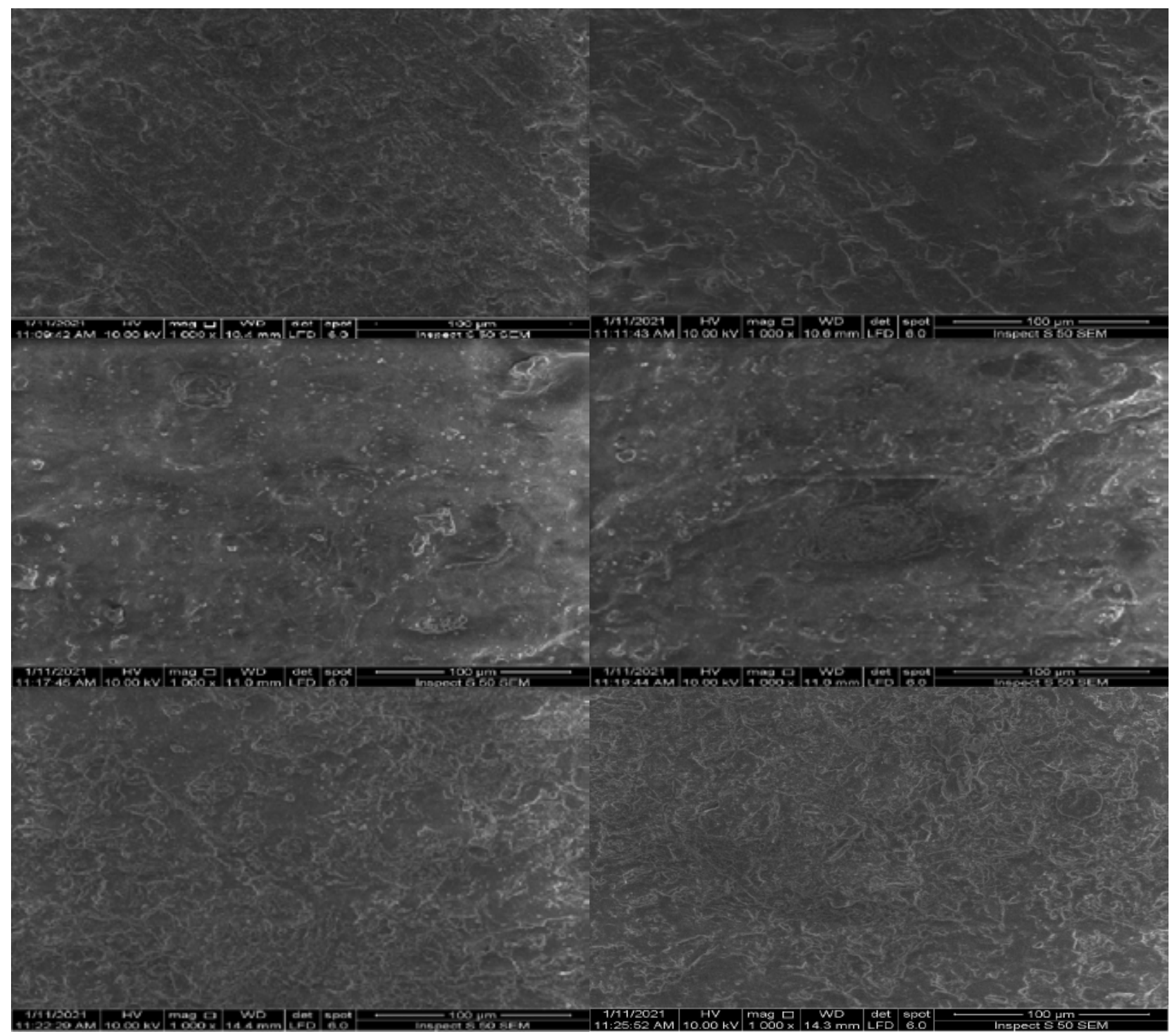

Figure 4 - (a-f). SEM for control groups nonautoclave(a) autoclave (b); Laser groups nonautoclave (c)autoclave (d);sandblast groups nonautoclave (e) autoclave (f) at X1000 amagnification. 


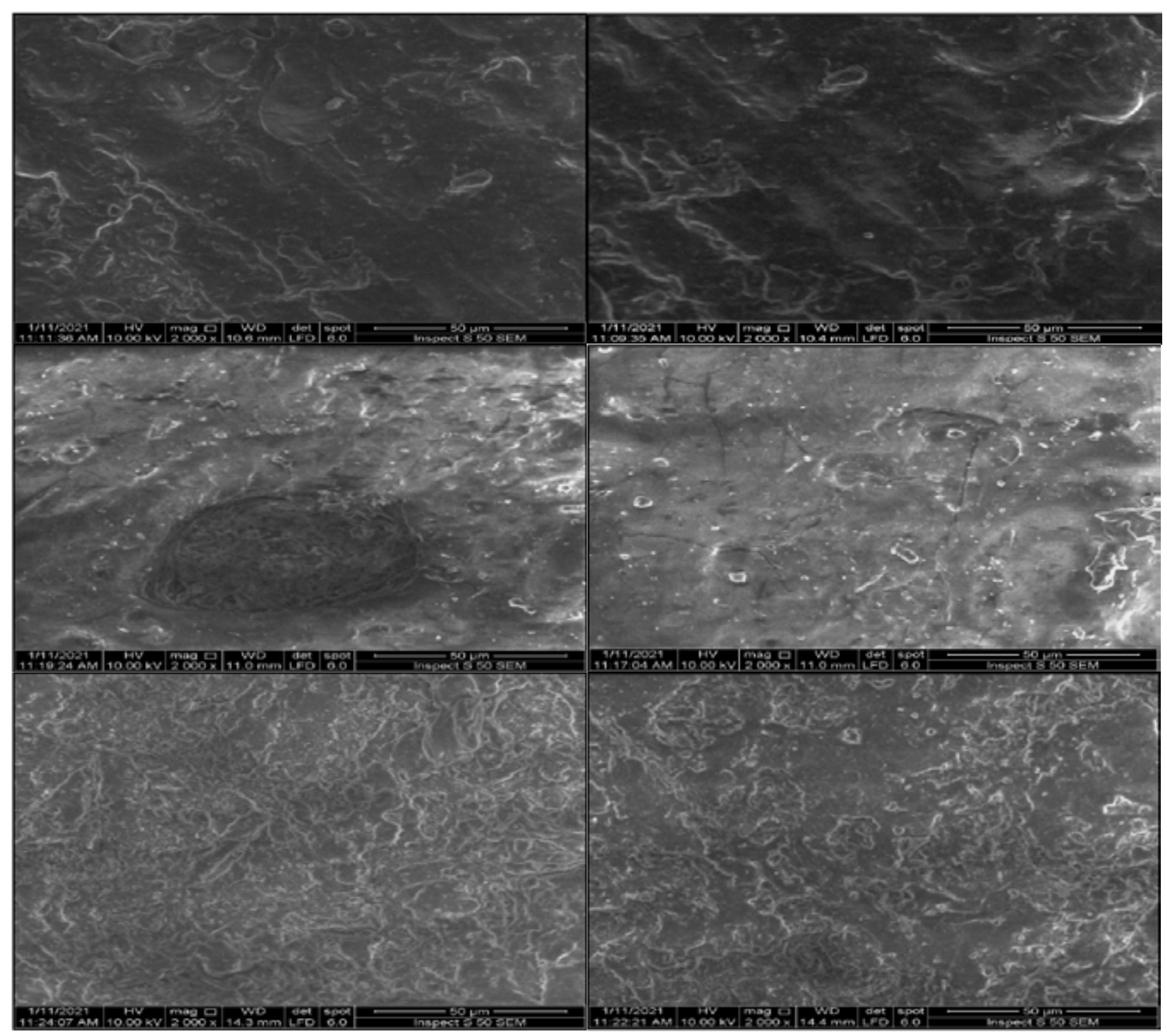

Figure 5 - (a-f).SEM for control groups nonautoclave(a) autoclave (b); Laser groups nonautoclave (c)autoclave (d);sandblast groups nonautoclave (e) autoclave (f) at X 2000 amagnification.

\section{DISCUSSION}

Soft liner materials have several important problems including loss of softness, colonization by candida Albicans, low tear strength, porosity $[14,32]$, but the loss of bond between the liner and the denture surface beneath it that produces microleakage which is considered the major one [33]. Therefore, the prevention of the leak between them is essential to increase the period of denture use [34]. To solve this perplexing problem the investigators have focused on methods to alter the denture base resin surface which is including the chemical and mechanical such as laser treatment [35]. According to the result of this study, pretreatment of the denture base resin with airborne particle abrasion by sandblasting with $250 \mu \mathrm{m} \mathrm{Al} \mathrm{O}_{3}$ and $\mathrm{CO}_{2}$ laser decreased the microleakage of soft liner material to acrylic resin denture base in comparison to the control group. So, the first part of the hypothesis was rejected. This result coincided with previous 
research that found the sandblasting of the denture surface with $50 \mu \mathrm{m} \mathrm{Al} 2 \mathrm{o} 3$ reduced the degree of microleakage by improving the bond strength between a silicon-based resilient lining material and denture base [12]. Also agreed with another study that found that roughening the denture base by sandblasting reduced microleakage for acrylic-based linings [27]. It was assumed that airborne particle abrasion of acrylic resin improved the bond strength of resilient lining material to the denture base, through the production of irregularities that could facilitate mechanical interlocking [36,37]. As well as, it believed that the roughening of the acrylic surface was affected the bond strength with soft lining material in a positive way [38]. Nakhaei et al. stated that airborne abraded group exhibited significantly higher bond strength than the control group [39]. The same result gained from Storer [40] and Uzumez et al. [36]. The enhanced bond strength in the result of Nakhaei could be attributed to the larger size of alumina particles $110 \mu \mathrm{m}$ that created larger pits and depressions, thereby, the resilient lining material could penetrate into them more easily [39]. The presence of definite cavities on surfaces hit by alumina oxide particles indicated this. On contrary, these larger particles were more easily removed from the surface of the liner and the acrylic resin, leaving fewer residual particles that exhibited less interference with the bonding procedure compared with smaller particles this was explained why the microleakage of sandblasting group in this study was reduced more than other treatment and control group. Adversely, Amin et al., concluded that the application of aluminum oxide was lowered the bond strength between the acrylic and liner which increased the microleakage[41]. The same result by Korkmaz and other researchers in 2013, who revealed the $\mathrm{Al}_{2} \mathrm{O}_{3}$ produced a weak bond between polyamide and silicon lining material[42]. On the other hand, the laser attracted attention as an alternative technique for the preparation of the surface of the acrylic resin before placement of the soft liner that results in suitable surface pits and roughness which in turn increase soft liner bonding [43]. In this study reduced the microleakage by treatment with the $\mathrm{CO}_{2}$ laser than the untreated surface this in agreement with studies that indicated that surface treatment with laser can be an effective technique in increasing the bond strength of liner to acrylic resin $[23,39]$. A study indicated that Er, Cr:YSGG laser improved the adhesion of the resin to the silicon[42]. Researchers found that ND: YAG laser treatment of PMMA increased the surface roughness and irradiated specimens exhibited higher bond strength to the resilient lining material, although the difference was not statistically significant [36]. Also, other research showed there was an improvement in the peel strength by surface treated with $\mathrm{Al}_{2} \mathrm{O}_{3}$ or $\mathrm{CO}_{2}$ laser, one of the factors that might affect the outcomes in laser group in different studies is the rate of scanning of the laser tip and the distance of the tip to the surface [26], the scan rate could result in different cavities on the surface of acrylic resin. The use of the laser in the focus or defocus mode might also affect the ability to create pits by the laser beams [44]. In this study in the comparison between $\mathrm{Al}_{2} \mathrm{O}_{3}$ group and $\mathrm{CO}_{2}$ laser group, the $\mathrm{Al}_{2} \mathrm{O}_{3}$ had decreased value of microleakage in comparison to $\mathrm{CO}_{2}$ laser this could be explained by the roughened acrylic denture base by laser might have pits in discontinuities manner that didn't lead to enough penetration of the liner into them that created gaps and oral fluids accumulation $[11,45]$. In addition, an irregular surface might produce contact angle and surface tension which resulted in decreases in the penetration of material into the irregularities on the acrylic. If the logic is applied to the penetration of liners into the irregularities produced by $\mathrm{CO}_{2}$ laser, increasing the viscosity of resilient liners for a given contact angle and surface tension reduces the penetration of the liners this might be explained the microleakage of the group treated by $\mathrm{CO}_{2}$ laser lower than the group treated by sandblasting [26]. 
These explination were supported by SEM observations that were revealed for Control groups, the SEM analysis clearly showed the specimens obtained the visual homogenous appearance with smooth topography than different treatments groups without changes in topography compared before and after autoclave disinfection [46]. While, SEM observation findings for laser groups explained by the discharge of laser energy promoted the surface changes such as the material removal due to the punctate nature of the laser induced micro explosions, resulting in the formation of voids, and fusing and melting of the most superficial layer followed by solidification to a smooth blisterlike surface [47]. On the other hand, sandblast groups were showed irregularities compared to the untreated specimen; also, remnants of the alumina particles were viewed on the surface that producing micro-retentive areas in which more wettability may occur on the surface, which may cause better flow due to the roughness obtained through them [48].

On the other hand, the obtained result of present study was revealed that the use of autoclave as a disinfection technique did not change the microleakage statistically so the second part of hypothesis was accepted. The design of autoclave depended on the pressure that was maintained by heating liquids above their boiling point for sterilization but the liquid water did not heat above $100{ }^{\circ} \mathrm{C}$ in an open vessel, further heating result in boiling but does not raise the temperature of the liquid water. As the container was heated, the pressure raised as a result of the constant volume of the container [49]. This explained the non-significant difference in microleakage between groups with sterilization by autoclave and groups without sterilization by autoclave, that was supported by the SEM images which indicated there was no alteration in morphology of the surface before and after autoclave disinfection for all groups.
One of the advantages of the present study compared with similar studies was the concomitant evaluation of the effect of different surface treatments with and without sterilization by autoclave on microleakage of soft lining material to acrylic resin denture base.

The limitation related to present research was the evaluation of microleakage should be done with more time of aging and autoclave sterilization. The condition of this research was in-vitro which might different from in-vivo conditions including fluctuation in the saliva $\mathrm{pH}$, different percentages of the salivary ions, presence of immunoglobulins, and serum markers in the saliva those factors could affect microleakage.

This study opens new scope for further research such as evaluation of the effect of other types of surface treatments for acrylic denture base on the microleakage between different types of soft liner and acrylic denture base resin and microscopic estimation after surface treatment of the soft liner bonded to acrylic resin.

\section{CONCLUSIONS}

Within the limitations of the present study, it was concluded that the sandblast treated group was showed a better reduction in microleakage than the laser-treated group in comparison to the untreated group. As well as, the use of autoclave for disinfection did not change the microleakage between the soft liner and acrylic resin.

\section{Acknowledgments}

Non

\section{Funding}

This study was self-funded.

\section{Conflict of interest}

The authors have no conflict of interest related for this study.

\section{Regulatory Statement}

Non 


\section{REFERENCES}

1. Valentini F, Luz MS, Boscato N, Pereira-Cenci T. Surface roughness changes in denture liners in denture stomatitis patients. Int J Prosthodont. 2017 November/December;30(6):561-4. doi: 10.11607/ijp.5108.

2. Dayrell A, Takahashi J, Valverde G, Consani R, Ambrosano G, Mesquita $M$. Effect of sealer coating on mechanical and physical properties of permanent soft lining materials. Gerodontology. 2012 Jun;29(2):e401-7. doi: 10.1111/j.1741-2358.2011.00487.X.

3. Bolayir G, Turgut M, Hubbezoğlu I, Doğan OM, Keskin S, Doğan A, Bek B. Evaluation of laser treatment on reline-base composites. J Adhes 2007;83(2):117-27. https://doi.org/10.1080/00218460701196598.

4. Mainieri VC, Beck J, Oshima HM, Hirakata LM, Shinkai RS. Surface changes in denture soft liners with and without sealer coating following abrasion with mechanical brushing. Gerodontology 2011;28(2):146-51. doi:10.1111/j.1741-2358.2010.00375.x.

5. Rathi S,Verma A.Resilient liners in prosthetic dentistry: an update. Int J Appl Dent Sci. 2018;4(3):34-8. doi: 10.1111/.j1741-2358.2012.00658.x.

6. Kasuga Y, Takahashi H, Akiba N, Minakuchi S, Matsushita N, Hishimoto M.Basic evaluation on physical properties of experimental fluorinated soft. Dent Mater J. 2011;30(1):45-51. doi:10.4012/dmj.2010-084.

7. Saravanan M, Kumar A, Padmanabhan TV, Banu F. Viscoelastic properties and antimicrobial effects of soft liners with silver zeolite in complete dental prosthesis wearers: an in vivo study. Int J Prosthodont. 2015 MayJun;28(3):265-9. doi: 10.11607/ijp.3740.

8. Pinto Lde R, Acosta EJ, Távora FF, da Silva PM, Porto VC. Effect of repeated cycles of chemical disinfection on the roughness and hardness of hard reline acrylic resins. Gerodontology. 2010 Jun;27(2):147-53. doi: 10.1111/.j.17412358.2009.00282.x.

9. 9. International Organization for Standardization, Dentistry-Soft Lining Materials for Removable Dentures Part 2: Materials for Long-Term Use, ISO/FDIS 10139-2, Switzerland, 1999

10. Mante FK, Mante MO, Petropolous VC. In vitro changes in hardness of sealed resilient lining materials on immersion in various fluids. $J$ Prosthodont. $2008 \mathrm{Jul} ; 17(5): 384-91$. doi: 10.1111//.1532-849X.2008.00303.x

11. Saraç YS, Başoğlu T, Ceylan GK, Saraç D, Yapici 0. Effect of denture base surface pretreatment on microleakage of a silicone-based resilient liner. J Prosthet Dent. 2004 Sep;92(3):283-7. doi: 10.1016/j.prosdent.2004.06.004.

12. Sabarigirinathan C, Muthukumar K, Vinayagavel K, Vinayakam S, Kumar $\mathrm{S}$, Rajakumar M, et al. A Comparative study of microleakage of heat cure silicone soft liner and self cure silicone soft liner with heat cure acrylic denture base after accelerated aging and surface treatment-an in vitro Study.Int J Health Sci Res. 2015;5(7):198-205.

13. Kawano F, Dootz ER, Koran A 3rd, Craig RG. Comparison of bond strength of six soft denture liners to denture base resin. J Prosthet Dent. 1992 Aug;68(2):368-71. doi: 10.1016/0022-3913(92)90347-d.

14. Meşe A, Güzel KG, Uysal E. Effect of storage duration on tensile bond strength of acrylic or silicone-based soft denture liners to a processed denture base polymer. Acta Odontol Scand. 2005 Feb;63(1):31-5. doi: 10.1080/00016350510019667.

15. Kimura Y, Yonaga K, Yokoyama K, Matsuoka E, Sakai K, Matsumoto K. Apical leakage of obturated canals prepared by Er:YAG laser. J Endod. 2001 Sep;27(9):567-70. doi: 101097/00004770-200109000-00003.

16. Payne JA, Pereira BP. Bond strength of two nonaqueous elastomeric impression materials bonded to two thermoplastic resin tray materials. J Prosthet Dent. 1995 Dec;74(6):563-8. doi: 101016/s0022-3913(05)80306-3.
17. Surapaneni H, Ariga P, Haribabu R, Ravi Shankar Y, Kumar VH, Attili S. Comparative evaluation of tensile bond strength between silicon soft liners and processed denture base resin conditioned by three modes of surface treatment: an invitro study. J Indian Prosthodont Soc. 2013 Sep;13(3):274-80. doi: 101007/s13191-012-0235-5.

18. Gopal KV, Padmaja BJ, Reddy NR, Reddy BM, Babu NS, Sunil M.Comparison and evaluation of tensile bond strength of two soft liners to the denture base resin with different surface textures: An in vitro study. JDr NTR Univ Health Sci 2014;3(2):102. doi: 10.4103/2277-8632.134850.

19. Alloaibi MA.Effect of autoclave on bacterial growth isolated from different types of denture adhesives. Iraqi Dent J. 2017;39(2):65-72. doi: http:// dx.doi. org/10.26477/idj.v39i2.125

20. Rai P.Infection control in orthodontics. Journal of Orthodontics,2015.1(1):p.1.

21. Kimoto S, Kobayashi N, Kobayashi K, Kawara M. Effect of bench cooling on the dimensional accuracy of heat-cured acrylic denture base material. J Dent. 2005 Jan;33(1):57-63. doi: 10.1016/j.jdent.2004.08.002.

22. Durkan R, Gürbüz A, Yilmaz B, Özel MB, Bağış B. Effect of autoclave postpolymerization treatments on the fracture toughness of autopolymerizing dental acrylic resins. J Appl Biomater Funct Mater. 2012 Jun 26;10(1):37-42. doi: 10.5301/JABFM.2012.9271

23. Al-Noori AK, Al-Kateb HM.Evaluation of microleakage of soft liners to highly impact acrylic resin. Al-Rafidain Dent J. 2012;16:378-85.

24. Nammour S, Gerges E, Bou Tayeh R, Zeinoun T. Oral crest lengthening for increasing removable denture retention by means of $\mathrm{CO} 2$ laser. Sci World J. 2014:2014:738643. doi: 10.1155/2014/738643.

25. Basir MM, Rezvani MB, Chiniforush N, Moradi Z. Effect of CO2, Nd: YAG and Er: YAG Lasers on Microtensile Bond Strength of Composite to Bleached-Enamel. Open Dent J. 2016 May 9;10:148-57. doi: 10.2174/1874210601610010148.

26. Jacobsen NL, Mitchell DL, Johnson DL, Holt RA. Lased and sandblasted denture base surface preparations affecting resilient liner bonding. $J$ Prosthet Dent. 1997 Aug;78(2):153-8. doi: 10.1016/s0022-3913(97)70119-7

27. Jaffer NT, Kazanji MN.The Effect of denture base surface treatments on microlekage of soft lining materials. Al-Rafidain Dent J. 2009;10:168-174.

28. Khanna A, Bhatnagar VM, Karani JT, Madria K, Mistry S. A Comparative evaluation of shear bond strength between two commercially available heat cured resilient liners and denture base resin with different surface treatments. J Clin Diagn Res. 2015 May;9(5):ZC30-4. doi: 10.7860/ JCDR/2015/11504.5892

29. Wilder AD Jr, Swift EJ Jr, May KN Jr, Thompson JY, McDougal RA. Effect of finishing technique on the microleakage and surface texture of resinmodified glass ionomer restorative materials. J Dent. 2000 Jul;28(5):36773. doi: 10.1016/s0300-5712(99)00075-5.

30. Mendonça e Bertolini Md, Cavalcanti YW, Bordin D, Silva WJ, Cury AA. Candida albicans biofilms and MMA surface treatment influence the adhesion of soft denture liners to PMMA resin. Braz Oral Res. 2014;28:61-6. doi: 10.1590/s1806-83242013005000025.

31. Salih $\mathrm{SI}$, Oleiwi JK, Hamad QA. Investigation of fatigue and compression strength for the PMMA reinforced by different system for denture applications. Int J Biomed Mat Res 2015;3:5-13.

32. Skupien JA, Valentini F, Boscato N, Pereira-Cenci T. Prevention and treatment of Candida colonization on denture liners: a systematic review. $J$ Prosthet Dent. 2013 Nov;110(5):356-62. doi: 10.1016/.jprosdent.2013.07.003.

33. Al-Athel M, Jagger R, Jagger D. Effect of ageing on the bond strength of a permanent denture soft lining material. J Oral Rehabil. 2002 Oct;29(10):992-6. doi: 10.1046/j.1365-2842.2002.00946.x. 
34. Garcia RM, Léon BT, Oliveira VB, Del Bel Cury AA. Effect of a denture cleanser on weight, surface roughness, and tensile bond strength of two resilient denture liners. J Prosthet Dent. 2003 May;89(5):489-94. doi: 10.1016/s0022-3913(03)00126-4.

35. Sarac D, Sarac YS, Basoglu T, Yapici O, Yuzbasioglu E. The evaluation of microleakage and bond strength of a silicone-based resilient liner following denture base surface pretreatment. J Prosthet Dent. 2006 Feb;95(2):143-51. doi: 10.1016/.jprosdent.2005.11.012

36. Usumez A, Inan 0, Aykent F. Bond strength of a silicone lining material to alumina-abraded and lased denture resin. J Biomed Mater Res B Appl Biomater. 2004 Oct 15;71(1):196-200. doi: 10.1002/jbm.b.30078

37. Akin H, Tugut F, Mutaf B, Akin G, Ozdemir AK. Effect of different surface treatments on tensile bond strength of silicone-based soft denture liner. Lasers Med Sci. 2011 Nov;26(6):783-8. doi: 10.1007/s10103-010-0825-6.

38. Eick J, Craig R,Peyton F. Properties of resilient denture liners in simulated mouth conditions. J Prosth Dent. 1962;12(6):1043-52. https://doi.org/10. 1016/0022-3913(62)90159-2.

39. Nakhaei M, Dashti H, Ahrari F, Vasigh S, Mushtaq S, Shetty RM. Effect of different surface treatments and thermocycling on bond strength of a silicone-based denture liner to a denture base resin. J Contemp Dent Pract. 2016 Feb 1;17(2):154-9. doi: 10.5005/jp-journals-10024-1819

40. Storer R.Resilient denture base materials. Part 1. Introduction and laboratory evaluation. Brit Dent. J. 1962;113:195-203.

41. Amin WM, Fletcher AM, Ritchie GM. The nature of the interface between polymethyl methacrylate denture base materials and soft lining materials. J Dent. 1981Dec;9(4):336-46. doi: 101016/0300-5712(81)90007-5.
42. Korkmaz FM, Bagis B, Ozcan M, Durkan R, Turgut S, Ates SM. Peel strength of denture liner to PMMA and polyamide: laser versus air-abrasion. J Adv Prosthodont. 2013 Aug;5(3):287-95. doi: 10.4047/jap.2013.5.3.287

43. al-Athel MS, Jagger RG. Effect of test method on the bond strength of a silicone resilient denture lining material. JProsthet Dent. 1996 Nov;76(5):535-40. doi:101016/s0022-3913(96)90014-1

44. Özdoğan A, Bayindir F, Hamza U. Bond strength of soft lining material to polyamide denture material. Atatürk Üniversitesi Diş Hekimliği Fakültesi Dergisi. 27(1): p. 34-38. https://doi.org/10.17567/ataunidfd.307109.

45. Minami H, Suzuki S, Ohashi H, Kurashige H, Tanaka T. Effect of surface treatment on the bonding of an autopolymerizing soft denture liner to a denture base resin. Int J Prosthodont. 2004 May-Jun;17(3):297-301

46. Cortés-Sandoval G, Martínez-Castañón GA, Patiño-Marín N, MartínezRodríguez PR, Loyola-Rodríguez JP. Surface roughness and hardness evaluation of some base metal alloys and denture base acrylics used for oral rehabilitation. Mater Lett. 2015;144:100-5. doi: 101016/j. matlet.2015.01.035

47. Kunt GE, Güler AU, Ceylan G, Duran I, Ozkan P, Kirtiloğlu T. Effects of Er:YAG laser treatments on surface roughness of base metal alloys. Lasers Med Sci. 2012 Jan;27(1):47-51. doi: 10.1007/s10103-010-0844-3.

48. Sari F, Ustun 0, Kirmali 0 . Efficacy of various pretreatments on the bond strength of denture teeth to denture base resins. Photomed Laser Surg. 2018 Apr;36(4):214-20. doi: 10.1089/pho.2017.4408

49. Durkan $R, 0 z e l$ MB, Bağiş $B$, Usanmaz A. In vitro comparison of autoclave polymerization on the transverse strength of denture base resins. Dent Mater J. 2008 Jul;27(4):640-2.

\section{Hawraa Khalid Aziz}

\section{(Corresponding address)}

Middle Technical University (MTU), Department of Prosthetic Dental Technology, College of

Health and Medical Technologies, Baghdad, Iraq.

Email: hawraa.khalid.azizaziz@mtu.edu.iq

Date submitted: 2020 Nov 05

Accept submission: 2021 Jan 21 